\title{
The Black Musician as Literary Hero: Baldwin's "Sonny's Blues" and Kelley's "Gry for Me"
}

By

Sigmund Ro

University of Trondheim

This essay presents two case studies of the intellectual and ideological sources of the black hero in Afro-Americanfiction. The two stories by James Baldwin and William Melvin Kelley have been selected because they are representative of their times and provide convenient mirrors of intellectual and ideological continuities and discontinuities in black American writing in the post-war era.

Art and culture intersect. To look at fictional heroes is at the same time to be looking at refracted images of cultural realities beyond the internal verbal structures of the literary artifact. In the words of Edmund Fuller, 'every man's novel may not have a thesis, but it must have a premise-whether declared or tacit, whether conscious or unconscious. ${ }^{1}$ That premise, without which no work of literature can be coherent or even intelligible, must ultimately be located in the extra-literary and extra-linguistic reality of the writer's culture. Character is perhaps the formal component most immediately dependent on such non-literary premises.

Black fiction in the post-war period illustrates this interdependence between society and art with particular clarity. In the first decade, the spirit of the black intellectual community was characterized by integrationist views and a wish to join the mainstream of American literary life. This tendency was exemplified by the use of white characters, milieus, and authorial postures in Ann Petry's and Willard Motley's fiction, and further buttressed by an emerging black critical establishment in the 1940's and '50's, trained in Northern graduate schools and rigorously applying the literary standards of white critics. Saunders Redding, Nick Aaron Ford, Nathan Scott, and Hugh Gloster were all agreed in urging black artists to emancipate themselves from 'the fetters of racial chauvinism $^{2}$ and to deal with universal human experience. 
In retrospect, it is not hard to discern the broader cultural context of this trend in black literary expression and criticism. In the overall effort of the black minority to achieve a position of equality in society, the strategy was understandably to emphasize the common humanity of black and white at the expense of the ethnocentricity and nationalism of the inter-war period. The same tendency prevailed in the Jewish-American community. In literary terms, this meant insistence on the writer's freedom to deal with his material in a non-racialist and universal spirit. Specifically, it meant literary characters created or interpreted in terms of archetypes or generalized human identity quests. In accordance with this mood, John Grimes of Go Tell It on the Mountain and Ellison's unnamed hero as well as Bellow's and Malamud's Jews were read as symbols of Youth, the Artist, or the human condition.

In this light, Baldwin's best known short story, 'Sonny's Blues' (1957), ${ }^{3}$ merits reconsideration in terms of the modern EuroAmerican intellectual stance underlying it which appears to have escaped critical notice. Reflected in Baldwin's portrait of a black blues artist is, for all his discovery of racial community noted by commentators, the whole integration ethos of the first post-war decade, stated in the familiar existentialist categories of the Left Bank coteries in which Baldwin moved between 1948 and 1958. Though not actively seeking admission to the white world, Sonny is conceived in the image of Kierkegaard-Sartre-Camus and provided with an authentic black exterior. Behind Sonny there looms the non-racial esthetic of the Baldwin who proclaimed in 1955 that he merely wanted to be 'an honest man and a good writer."4

With the radicalization of the civil rights movement, the new militant nationalism, and the impact of African liberation, the literary situation for the black writer changed, spelling the end of the esthetic upon which Baldwin's Sonny was predicted. Négritude or soul gradually became a focal point of black cultural activity, involving separatist notions of artistic creation and the role of the artist.

The dimension of Négritude which has informed so much recent black writing is less the political implications of Pan-Africanism than the highly effective mystique of blackness as a special moral and spiritual sensibility which has evolved out of the writings of such theoreticians as Aimé Césaire, Alioune Diop, and Léopold Senghor. ${ }^{5}$ Here Négritude is thought of as a distinct ethos; that is, a body of traits, habits, and values crystallized into a peculiar life style and 
producing a psychology common not only to black Africans, but to blacks living in the American diaspora as well. It involves a sense of self and community which derives from an exclusive group identity forged by a unique historical experience or even, as intimated by Senghor, having its origin in biological-genetic facts. It is a condition as well as a fate, preceding and transcending the vicissitudes of economics, politics, and history. Thus, at the 1956 Conference of Negro African Writers and Artists in Paris, Senghor could appeal to American blacks to reinterpret their literature in terms of their common heritage of Ne'gritude, taking himself the first step by discussing Richard Wright's poetry and Black Boy as African works.

In America, the corresponding concept of soul, if not the word itself, existed well before the historical Ne'gritude movement. Although not interchangeable concepts, they share a vision of a 'Soul Force, ${ }^{\prime 6}$ a unique source of moral and spiritual energy, peculiar to blacks everywhere. The real boost of the soul ethos and its ideologization for political and literary uses, however, occurred with the coinciding emergence of the latest phase of the civil rights movement in the U.S. and the African liberation from European colonialism in the late 1950's. The impact of soul was soon felt in black writing, especially as LeRoi Jones's seminal influence made itself felt after 1964, and led, in its extreme form, to a de-emphasizing of the mimetic principle of the Western conception of art and its traditional distinction between 'art' and 'life,' stressing instead the oral, utilitarian, and communal nature of African art as an ideal for black Americans to emulate.

Of the writers responding to the new currents, William Melvin Kelley has established himself as a major figure. As the decade of the 1960's unfolded, he found himself carried farther and farther away from the assimilationist position from which he started out. Trained at the exclusive Fieldstone school in New York before admission to Harvard and teaching posts at the New School for Social Research and Bard College, he started out in the familiar style of the privileged 'token Negro' bent on seeking acceptance and success in white America. At first, his artistic credo gave no cause for alarm. His self-confessed intention, as stated in the preface to Dancers on the Shore, ${ }^{7}$ was reassuringly within the accepted pattern of depicting human reality in universal terms, conceiving of himself as a detached artist with no obligations to provide social and political answers.

Even as he was stating his credo, however, Kelley was troubled by 
its inadequacies. Not unlike LeRoi Jones, whose starting-point bad been similar to his own, he found himself moving closer to a militant and racial esthetic under the impact of social and ideological developments in the black community. His public break with white America came in 1967, two years after Jones's defection from the New York literary establishment whose favorite talent be had become.

The beginnings of Kelley's new ars poetica, derived from soul and committing him to the creation of a racial art addressed to black audiences, can be traced back even to his earliest work. The work that most clearly pinpoints this transition process is perhaps the story entitled 'Cry for Me' (1962) ${ }^{8}$ which, in spite of the preface to Dancers on the Shore, where it was first published, bespeaks a growing restlessness with previous esthetic assumptions and a sympathetic response to the soul ethos that lie now appears to have embraced with few qualifications. Appropriately placed at the end of the volume, this story foreshadows ideas to be further developed and reinforced in his later fiction while at the same time typifying the changing character of black literary expression in the past decade. Together, Baldwin's and Kelley's two stories provide interesting case studies of what happens to fiction when it is subjected to the pressures of ideological change.

1.

The two stories lend themselves particularly well to a comparative analysis of the black literary hero because the external formal frameworks are so similar. The geographical settings overlap almost completely. Except for short excursions into the Bronx neighborhood of Carlyle's family, both stories move within a world circumscribed, physically as well as symbolically, by Harlem and Greenwich Village. In both, Village cabarets play central roles as scenes of epiphanic illuminations in the lives of the two narrators. To each story the urban setting is indispensible either as the source of the peculiar strains and frustrations of the characters or as a foil to the unadulterated pre-urban black 'soul.' The characters operate within the same structural pattern. In each case, the story hinges on the opposition of two characters, related by blood, but opposed in every other respect. One is a bourgeois Negro and the narrator of the story, the other is a 'soull' character with no desire to join the middleclass Establishment to which his relative belongs or to which he aspires. Sonny's brother is already firmly ensconced in the black 
bourgeoisie, while Carlyle appears to be bent on making it in the white world into which his family have moved since their beginnings in Harlem. In both cases, the development of the characters lends itself to description in terms of the 'initiation' pattern. Carlyle and Sonny's brother both grow from either a state of ignorance or guilty innocence to higher levels of consciousness through contact with their soulful relatives. This pattern is also the principle governing the two plots. In either case, a narrator whose presumed superiority makes him adopt the role of teacher and authority, receives a relative who is seen as ignorant, innocent, or immature. Ironically, both plots proceed to overturn this relationship by reversing their relative positions. By the end of the stories, the visitors have become the teachers and authorities by virtue of their charisma and insight while the narrators have been relegated to the position of humble apprentices and recipients of their mentors' messages. Thus the narrative structures are made to serve the educational process in the two characters initiated into the mysteries communicated by the black heroes whose medium of expression is, in both cases, music. Finally, the realism of the two stories is modified by the same set of symbols and images. Sonny and Uncle Wallace both become high priests and their concerts ceremonial occasions re-enacting semi-religious dramas of sacrifice and redemption.

This formal resemblance makes the differences in the larger implications of the two musician-heroesstand out all the more clearly. It would seem, however, from the criticism elicited by 'Sonny's Blues,' that this aspect has not been given the attention it deserves. Commentators appear unanimous in their emphasis on the racial element as it appears in the hero's individual identity quest within the boundaries of black culture. Both Marcus Klein and Shirley Anne Williams agree that the thrust of Sonny's message is the expression of his black identity. He is, in Klein's words, 'full of unspecified Negroness,' his problem is the 'burden of his racial identity' to be expressed through his music. Ultimately, the story undertakes to reveal 'the Negro motives that may issue in the blues.' Shirley Williams is willing to see Sonny as the typical alienated artist of so much twentieth-century literature, but she insists that his main 'referent is Black lives, Black experiences and Black deaths.' His estrangement is primarily an estrangement from his 'ancestral past. 10 The cure can only be effected through a restoration of the relationship between his personal history and that of his 
racial group. This delicate, but healing balance between private and group selves Sonny is finally able to achieve in his solo performance within the context of Creole's jazz band. On the other hand, Edward Margolies sees Sonny's music as a means of selfexpression reflecting Baldwin's Christian-Protestant heritage. Even so, however, he sees Sonny's outbursts of 'the grief and terror that rage within his soul' as patterned on the testimony of the redeemed saint in the presence of witnesses, presumably to be equated with the audience, thus ultimately relating the story to the black religious tradition of the storefront church as the context of the protagonist's identity quest. ${ }^{11}$

It cannot of course be denied that Sonny's art is conditioned by racial factors. His despair is the despair of the sensitive black ghetto youngster feeling the stifling effect of his environment. His need to escape is easily attributable to fear of victimization by the same forces that turn his brother's students into drug addicts or naturally sensuous women into the frenziedly pious church sisters testifying in the street. The music has a direct therapeutic function, permitting him to contain his pent-up frustration and even enabling him to temporarily transcend his circumstances. Sonny needs his music to master his potentially self-destructive anger at being trapped in a black slum. He must play not to smash somebody's skull, his music is a form of mental hygiene. In this respect, the psychology involved is essentially the same as that of other musician- or artist-heroes in Baldwin's work or of Clay Williams in Dutchman.

As Sonny realizes the deeper implications of what he is playing, his music acquires the significance it has in Go Tell It on the Mountain and in Baldwin's essays: that of putting himself and his audience in touch with their common ancestral past. In the final scene, it evokes in his brother's mind the reality of family, forefathers, and community in black life. Memories are stirred of childhood scenes of Sunday afternoon reunions of relatives and 'church folks' huddled together against the darkness of the outside world. In an attempt to impress upon him the necessity of protecting Sonny, their mother tells him of the murder of his uncle by white men and the traumatic effect of this experience on her husband. At the piano, Sonny becomes a high priest invoking the collective and accumulated experience of 'that long line, of which we know only Mama and Daddy' - one of the central images in the first novel- and mediating with the authority of a shaman between the living and the dead members of the tribe. Throughout this ever expanding perspective 
from present into past, from personal experience into family history and the history of 'that long line,' this telescoped racial history, captured and re-enacted by Baldwin's musician-hero, is evoked literarily in the story in images of light and darkness. There is a consistent - and ironic - association of light with black community feeling and togetherness and of darkness with a racist and oppressive white world. Thus Sonny's music has an unmistakable racial core. It functions as a means of escape from the ghetto and as a psychological buffer to his bruised black ego by enabling him to identify with and draw strength from the past and the present group experience of his race.

This concern with his racial heritage is a prominent feature in Baldwin's other early work as well. Originally intending to escape the burden of race through a self-imposed exile, he gradually discovered the futility of such an endeavor. Cast in the form of the personal myth writers often create of their artistic coming of age, his account in 'Stranger in the Village'12 tells the story of how he immured himself in a Swiss village armed only with a typewriter and Bessie Smith records in order to put himself through the painful process of overcoming his feelings of shame and self-hatred through unconditional self-acceptance. Out of this experience was born his first novel. The problem of self-acceptance continued to haunt him, however, until he returned to make peace with his native land and go South in search of his ancestral roots in the late 1950's. Written in 1956-57, 'Sonny's Blues' can be directly related to the author's concern during the first post-war decade with coming to terms with the fact and meaning of being black in a racist white world which imposes upon its racial minorities its own notions of superiority and inferiority. The resulting syndromes of self-destructive flight into 'white' values and behavior patterns and the opposite impulse of revolt generated by this imposition are demonstrated by the narrator and Sonny respectively. In fact, one might view this antithetical grouping of the two main characters as a reflection of the latent tension in Baldwin's own imagination between his ambivalently alternating identifications with the black masses and the world of the black and white middle-class in a way which is strongly reminiscent of Langston Hughes's self-confessed projection of similar conflicting impulses in himself into the folk character Jesse B. Simple and the genteel, intellectual narrator in his war-time sketches in the Chicago Defender.

In Baldwin's story this tension is resolved in favor of Sonny's 
identification with his racial past and his brother's 'conversion' to a similar position, symbolized by the ritual of sharing a sacramental drink in the final scene. This racial self-acceptance is, however, a more complex matter than has hitherto been recognized. While certainly genuine and valid in racial terms, the identity achieved ultimately transcends race to become a statement on the human condition in the modern world in a universal sense. Furthermore, it can be demonstrated in considerable detail that the story's universalizing formula derives from the concepts and, occasionally, the explicit vocabulary of contemporary existentialist thought.

As already pointed out, Baldwin's story in this respect parallels the familiar pattern in post-war literature and criticism of employing racial heroes as archetypes of the modern human predicament. Characteristically, Jean-Paul Sartre's interest in Richard Wright's work is based on the supposed susceptibility of the alienated outsider-victim to interpretation in general existentialist terms. Black critic Esther Merle Jackson's essay, 'The American Negro and the Image of the Absurd,' rests on the assumption that there is an essential likeness between Bigger Thomas, Ellison's invisible man, and Faulkner's Joe Christmas and, on the other hand, the heroes of Dostoevsky, Proust, Gide, Malraux, Mann, and Sartre. ${ }^{13}$ Indeed, in the case of Native Son and The Outsider, it has become almost a critical commonplace to regard their black protagonists as symbols of suffering, alienated, rebelling mankind. In the same critical tradition, the theologian-critic Nathan A. Scott has pointed to the kinship of Wright's writings with what he calls 'a main tradition in the spiritual history of the modern world.'14 Scott's specific reference is to the French-inspired existentialist mode of thought, notably in Camus's version, and the grounds for the alleged sameness of the black and the existentialist experience is the analogy of the Negro's historical familiarity with anxiety, violence, rejection, nihilism, and revolt with similar phenomena in Europe as a result of the ravages of global war and totalitarian politics. The reality of the concentration camp - whether in Germany or in Mississippiis the common ground on which the black American and the modern European meet.

Indeed, the basis for such a parallelism between the black experience and the condition of modern man was prepared by Wright himself in his threefold conception of Bigger as simultaneously a 'bad nigger,' proletarian class hero, and a symbol of uprooted modern man in an industrial and technological civilization. ${ }^{15}$ This was 
further emphasized and elaborated in White Man, Listen! (1957), where he reminded his European audience that the Negro, brutally uprooted from his tribal origins in Africa and transplanted to a Western world already in the throes of the industrial revolution, epitomizes the fate of the Westerners themselves in the modern world: 'So, in historical outline, the lives of American Negroes closely resemble your own. . . . The history of the Negro in America is the history of America written in vivid and bloody terms; it is the history of Western Man writ small. It is the history of man who tried to adjust themselves to a world whose laws, customs, and instruments of force were leveled against them. The Negro is America's metaphor.' ${ }^{16}$ In his own fiction, Wright dramatized this universal perspective not only in the character of Bigger Thomas, but even more explicitly in Fred Daniels in 'The Man Who Lived Underground' (1944) and in Cross Damon.

The same tendency to see the Negro in universal and symbolic terms is present in Baldwin's work in the 1950's, prompted by the same desire after the War to play down racial differences in favor of a global vision of mankind and environmental explanations of racial characteristics. After his disappointing encounter with black Africans in Paris, he discovered the close resemblance of his own experience with that of white Americans: 'In white Americans [the American Negro] finds reflected-repeated, as it were, in a higher key-his tensions, his terror, his tenderness. ${ }^{17}$ The experience is the same as Wright's, except that, interestingly, for Baldwin it seems to be the other way round: It is the white man's condition which epitomizes his own.

Thus Baldwin and his musician-hero can be seen as placed squarely within the mainstream of both black and white racial thought in the first post-war decade. Intellectually, they are akin to the ontology and idiom constituting the framework of black writing before the racial revolution of the 1960's, reflecting the prevailing ideology of a black intelligentia striving to de-emphasize the stigma of race through integration and universalizing formulas. Through the twist he gives to Wright's metaphor Baldwin reveals the ideological perspective of his first post-war position. Somewhat unkindly put, the implicit strategy is to plead for the Negro's equal worth by stressing that the same 'tensions,' 'terror,' and 'tenderness' that move the white man also move him. The closeness of this argument to the white liberal position is neatly revealed by comparing it to the premise of Kenneth Stampp's study of slavery from 
1956: '. . . innately Negroes are, after all, only white men with black skins, nothing more, nothing less. ${ }^{18}$

It is within this larger context that Sonny yields up meanings beyond his narrowly racial significance which critics so far have tended to stress. In the effort to make him a modern man fully as human as his white brother, Baldwin turned to the concepts and vocabulary of existentialism flowing into Europe and America from the Paris in which he was living. On this background, Sonny acquires a definable 'intellectual physiognomy'19 and his ideological implications can be more clearly perceived. It is significant that the straining toward integrated and universalizing statements on man's existential condition has a special urgency in the case of black heroes. In the 1950 's, it was imperative to assert the universal humanity of the racial hero in order to overcome the tragic legacy of racism in Western culture.

This is not to say that Sonny is an intellectual or a simple embodiment of clear-cut ideological aims. As George Lukacs points out, a literary character does not have to operate consciously on a high level of abstraction and verbal articulateness in order to have an intellectual physiognomy. Nor is there any need for authorial analysis and comment. Intellectual assumptions and attitudes are, and indeed should be, embedded in the whole range of responses to the pressures to which he is subjected. In Baldwin's story, instead of conceptualizing and articulating his hard-won insight verbally to his brother, Sonny prefers to expose him directly to its musical expression. Similarly, his brother's 'conversion' to Sonny's message is not presented in terms of intellectual discovery, but as a direct revelation and a ritualized initiation suggested by his symbolic non-verbal gesture of buying a sacramental 'Scotch and milk' for Sonny as a token of their communal sharing of a new wisdom. Sonny's intellectual profile and ideological significance emerge from the totality of his story, not from self-conscious philosophical contemplation or crude propaganda statements.

The existentialist concept most immediately visible in Baldwin's story is the Sartrean distinction between authentic and inauthentic living. Central to Sartre's distinction is the idea of self-delusion. Having defined man's situation as 'one of free choice, without excuse and without help,' he argues that 'any man who takes refuge behind the excuse of passion, or by inventing some deterministic doctrine, is a self-deceiver.' The inauthentic life is that which 'seek[s] to hide from itself the wholly voluntary nature of existence and its 
complete freedom.' Conversely, the authentic person is he who actively wills freedom, 'that man ... whose existence precedes his essence... who cannot, in any circumstances but will his freedom,' and who therefore cannot but will the freedom of others. ${ }^{20}$

The character in the story who most obviously reflects the concept of inauthenticity is Sonny's brother. His whole life is an elaborate structure of false props, based on exclusion of large hunks of reality, and erected in panicky pursuit of that bourgeois chimera: 'safety.' Incapable of facing the terror of Sonny's life, he says: 'I was dying to hear him tell me he was safe.' Constantly, he dodges reality. He does not want to believe that Sonny is being destroyed, or to know how he must feel: 'I didn't want to believe....,' 'I certainly didn't want to know,' 'I guess it's none of my business.' Whenever the dark forces with which Sonny is involved threaten his carefully constructed illusion of safety, he panicks. A fear that feels like 'a great block of ice' settles in his belly. The idea of Sonny preferring the bohemian life style of the artist to a respectable career, or jazz and the blues to classical music, arouses in him vehement reactions of fear and anger that clearly betray anxieties beyond brotherly love and solicitude. In his puritan and middle-class mind, black music is associated with intimate knowledge of the realities of existential chaos and absurdity.

Ultimately, what the narrator's anger conceals, is his guilty failure to stop deceiving himself and to heed his mother's words that 'Safe, hell! Ain't no place safe for kids, nor nobody.' It is hardly accidental that he is forever watching life through windows: subway windows, classroom windows, cab windows, and living-room windows. His is a life of non-involvement and detachment behind a fragile glass structure liable to crack or break at any moment. The only advice he is able to offer his brother is derived from the clichés he has adopted from the bourgeoisie he is aping: 'I wanted to talk about will power and how life could be-well beautiful.' In short, self-reliance and the sure reward of virtuous living. The algebra he teaches is an accurate symbol of the kind of orderly and predictable world he attempts to establish for himself. Seeking refuge in a 'safe' profession, a conventional marriage - the safety of which is ironically negated by the sudden death of his daughter - and conventional ideas, Baldwin's narrator consistently avoids facing 'the voluntary nature' of existence, thereby denying freedom not only to himself but to Sonny as well. He commits what in Sartre's terms is the ultimate sin, the very hallmark of inauthenticity: willed self deception. 
On the other hand, Baldwin's black musician-hero lends himself to description in positive existentialist terms. This is not to say that Sonny is reducible to a simple set of philosophical abstractions. In the same way that his brother's evasions are in part responses to his need to escape suffering and degradation, Sonny's acts stem from his need to break the drug habit and avoid self-destruction. Knowing the precariousness of human life in the ghetto, they are involved in real, down-to-earth problems of survival which are part of the story's fictionally established social illusion.

Within this framework of racial and social realism, however, Sonny is endowed with a peculiar charisma and insight into the nature of human existence. A clear indication that Sonny is meant to carry philosophical-ideological meaning is the repeated emphasis on the mythic dimension of his cha acter. Isabel confesses that having Sonny in the house 'wasn't like living with a person at all.' $\mathrm{He}$ is not so much a flesh-and-blood human person as 'god ... a monster.' It is as though he is 'all wrapped up in some cloud, some fire, some vision all his own.' He is beyond reach, a mystical 'presence' or force. The nightclub is his 'kingdom' where 'his veins bore royal blood.' From the beginning, his peculiar 'privacy' is insisted upon. He moves in a world all his own, a solitude in which he is supremely alone with his 'visions.' While he is performing, his fellow players are seen gathering around him on the stage as if offering up prayers to him: 'Every now and then one of them seemed to say, amen.' No doubt, Baldwin is at pains to establish Sonny as a vehicle expressing a vision of human life, a type embodying truth beyond the literal and specific problems in which he is involved. In several important respects, Sonny comes as close to Absurd Man as any American literary hero of the 1950's. Such concepts as Dread (Angst), nausea, alienation, and absurd freedom sum up his isolated stance as outsider-hero with considerable accuracy.

His disenchantment with America and its discredited Christian cosmology has begun at an early age. At 14 , 'he'd been all hipped on the idea of going to India.' He is attracted to Oriental mysticism and the true spirituality of 'people sitting on rocks, naked, in all kinds of weather ... and walking barefoot through hot coals and arriving at wisdom.' The Western myths of rationalism and automatic evolutionary progress are rejected in favor of subjective quests for personal truths and static or cyclic concepts of time. In a letter he writes his brother, he states explicitly his religious apostasy: 'I wish I could be like Mama and say the Lord's will be done, but I 
don't know it seems to me that trouble is the one thing that never does get stopped and I don't know what good it does to blame it on the Lord.' The educational system has nothing to offer. Nothing in it corresponds with his perception of reality: 'I ain't learnt nothing in school . . . Even when I go.' Eventually he drops out.

But his disillusionment goes deeper than any specific grievances he may have against society. The meaninglessness he feels at the sight of the big city jungle that surrounds him has its roots in an awareness that human existence itself is dislocated. The 'vision all his own' which he has had in his solitude is a vision of the irreconcilible divorce between man and his world. In prison, he has experienced the palpable reality of Nothingness: 'I feel like a man who's been trying to climb up out of some deep and funky hole.' He has discovered the ludicrous indecency of human suffering. Watching the revival meeting in the street, he experiences anew the nihilist's revulsion for the universe: '. . . listening to that woman sing, it struck me all of a sudden how much suffering she must have had to go through ... It's repulsive to think that you have to suffer that much.' He has encountered 'the roar rising from the void,' and he has felt that nauseous 'storm inside.' Playing the blues means facing it again and again as he 'leave[s] the shoreline and strike[s] out for deep water,' every time running the risk of 'drowning in it.' This experience generates in him a feeling of the unreality of reality: 'it was that they weren't real,' accompanied by a feeling of utter estrangement from it all, including his own self: 'I can't forget-where I've been. I don't mean just the physical place I've been, I mean where I've been. And what I've been . . . I can't really talk about it. Not to you, not to anybody ... I was all by myself at the bottom of something, stinking and sweating and crying and shaking, and I smelled it, you know? my stink. . . .'

What Sonny is haltingly, stumblingly trying to convey in words and imagery of chaos, disorder, and nothingness is ultimately Kierkegaard's 'sickness unto death,' Sartre/Roquentin's 'nausea,' and Camus/Meursault's experience of absurdity and unreality. ${ }^{21}$ In the final analysis, Sonny is the ego recoiling passionately from the human condition, opposed to it by his whole consciousness and instinctual urge toward order and familiarity. It is not fear that he experiences, but Angst-that self-generating, abysmal dread when confronting le grand néant. He has become Absurd Man doomed to living, in Camus's phrase, 'without appeal.' He has discovered the truth about the 'wholly voluntary nature of existence,' life as total 
possibility, total freedom, total responsibility. Indeed, he has realized that 'existence precedes essence,' that there is no preordained human nature, that identity is created by the self through its choices and acts. In Camus's terminology, he is a 'metaphysical rebel' whose insurrection is ultimately bound to dispute 'the ends of man and creation.'22 The human condition is perceived as fundamentally unintelligible, which explains his words that it is the instinct of any man who has looked into the naked terror of an absurd universe to resort to any means to repress the truth 'in order to keep from shaking to pieces.'

It is significant that at no time does Sonny feel guilty about his absurdist vision: 'I'm not talking about it now because I feel guilty or anything like that-maybe it would be better if I did, I don't know.' Sonny's words here are a near-verbatim echo of Camus: '[Absurd Man] does not understand the notion of sin ... An attempt is made to get him to admit his guilt. He feels innocent. To tell the truth that is all he feels-his irreparable innocence. ${ }^{23}$ To Sonny's brother there is something almost obscene and immoral about such a view of life. To him life is a rational and anti-tragic affair in which prudence, will power, and hard work will remove all obstacles to that 'beautiful' world of progress, success, and safety which he is chasing. According to his smug vision, Sonny's ideas are the result of his perverse pride. Therefore he attempts to impose upon Sonny a feeling of guilt by pointing out how perversely 'unreasonable' he is. For Sonny to pursue his vision is labelled as a 'sin' against Isabel's desire to live respectably, a 'sin' against himself trying to make it in society, and even a sacrilegeous crime against the memory of their dead mother. These charges fall completely outside Sonny's frame of reference, however. Sonny's 'irreparable innocence' cannot conceive of any such notion of sinfulness and criminality.

It gradually dawns on the narrator that Sonny's music grows out of a valid existential experience. Being told by Isabel's relatives about the fanaticism with which Sonny practices, he realizes that the music is 'life or death' to him. His 'education' is completed in the Greenwich Village nightclub when he discovers that Sonny's 'tale' is not just his own personal story, or the story of his race's trials and tribulations, but that 'this tale ... has another aspect in every country, and a new depth in every generation.' The blues revive memories not only of the troubles of 'that long line,' but also of the non-racial death of his little daughter from polio. Sonny's message 
expands into the timeless tale of human suffering, of the irrationality and sheer contingency of existence, and of the 'freedom that lurked about us.' Describing the impact of the music on the audience .and on himself, he feels that it hits something in him, and he senses the growing mood of 'apprehension' as Sonny and Creole begin to 'tell us what the blues were all about.' Thus what the music does is to create in the presumably interracial audience an experience of existential anguish and a heightened awareness of life as total freedom: 'Freedom lurked around us and I understood, at last, that he could help us be free, if we would listen, that he would never be free until we did.' For Sonny, as for Camus's metaphysical rebel, the reason for his inner freedom is the knowledge that there is no Suture. Like Sisyphus endlessly pushing the boulder back up to the top of the hill, he is doomed to playing the blues. His life must be a life in the present, an indefinite succession of blues acts paradoxically bestowing upon him the same modicum of freedom that Sisyphus enjoys. Sonny's freedom lies in his awareness of the nature of existence, and it is this awareness which liberates him to live to the maximum here and now. The meaning of his life is in the struggle itself. As with Sisyphus, one must imagine Sonny happy.

Defining the blues in terms close to the existentialist sensibility, Ralph Ellison states:

The blues is an impulse to keep the painful details and episodes of a brutal experience alive in one's aching consciousness, to finger its jagged grain, and to transcend it, not by the consolation of philosophy but by squeezing from it a neartragic, near-comic lyricism. As a form, the blues is an autobiographical chronicle of personal disaster expressed lyrically.... Their attraction lies in this, that they .at once express both the agony of life and the possibility of conquering it through sheer toughness of spirit. They fall short of tragedy only in that they provide no solution, offer no scapegoat but the self. ${ }^{24}$

This description fits Baldwin's Sonny to a remarkable degree. His music is nothing if not 'an autobiographical chronicle of personal disaster expressed lyrically' and thereby made representative of the lot of all men. The extent to which it is a self-transcending endeavor is suggested by the elaborate ritualization surrounding the concert from the solemnly 'ceremonious' appearance of the players on the bandstand to the subtle interaction between the soloist, the group, and the audience. The performance is metaphorically represented as a progsessive movement away from the safe shoreline out into deep water, punctured only by voices whispering 'amen' as new mysteries are revealed. They all gather around 
Sonny as their priest-shaman, vicariously facing the void through him and his music, and partaking of the freedom he is able to wrestle from it by 'imposing order on it.' The last stage of the narrator's development, especially his final act of sharing a sacramental drink with his brother, is modelled on the pattern of baptism, Holy Communion, and initiation. The effect of this ritualization is to make Sonny's art a public act and a communal experience to be shared. In the final scene, Sonny becomes the bard and the truthsayer of all mortals. Acting as their voice and mediator, lie is assigned the public function of officiating at a communal ritual of exorcism. Darkness is momentarily pushed back, the forces of destruction appeased. Riding on the waves of Sonny's artistically ordered sound, they enjoy a common triumph, however short-lived, over chaos. Ultimately, then, Baldwin's black musician has transcended both his private destiny and his role as a racial voice to become the modern existentialist Isolato speaking, 'on the lower frequencies, ${ }^{25}$ for all human beings. Before the fact of absurdity, all racial and personal distinctions fade away, and the blues become the tragic song of all men.

This is the trans-racial Sonny the story has been straining toward all along, and the underlying ideological requirements motivating Baldwin's character portrayal have already been hinted at. That such an interpretation is not wholly arbitrary is demonstrated by a recent short story by Sam Greenlee which is an explicit rebuttal of 'Sonny's Blues' on ideological grounds. ${ }^{26}$

Coming out of the new mood of blackness and celebration of racial solidarity among the post-Wright-Ellison-Baldwin generation, 'Sonny's Not Blue' is designed to counteract what the author sees as the spirit of 'white' individualism, integrationism, and defeatist resignation in Baldwin's story. Greenlee's Sonny is firmly anchored in the community and his actions subject to scrutiny by the group. Faced with the necessity of doing better in school, he does not, like his namesake of 15 years before, drop out, but receives the full support of his racial group who actively encourage him to improve himself so that his achievement will reflect favourably on the whole group. All the blacks in Sonny's housing project feel and act as one family. Whenever the welfare checks arrive late, the principle of group cooperation and solidarity starts operating. There are communal celebrations every time someone stops conking their hair and starts wearing a "'Fro.' They all stick together in manipulating the welfare agency. The 'white' Standard English insisted upon by 
the school system is rejected in favor of Black English. Healthy, unpolluted soul food is eaten. Sonny's mother is no meek praying woman scrubbing the white folks' floors, but a proud, resourceful person who takes Sonny to concerts at the Afro-Arts Theatre. The milk he drinks is 'Joe Louis milk,' and when he dreams of buying his mother a color television set, it is for the purpose of enabling her to watch the black color of Aretha Franklin's skin.

The spirit of the story is in deliberate contrast to 'Sonny's Blues.' The virtues of blackness are extolled. The social life of the group seems patterned on African-style village communism in which the individual has no life apart from the tribal family and where individual ambition finds its fulfillment within the context of the group. In contrast to the defensively struggling loner in Baldwin's story, Greenlee's black characters realize themselves through racial solidarity and collective action. His Sonny is emphatically not 'blue.' Reclaimed by his Afro-American tribe, he is not tainted by the spirit of resignation and decadent despair in which Baldwin's 'whitewashed' Sonny, cut off from his tribal roots, permits himself to indulge. Seen from Greenlee's ideological standpoint, Baldwin's existentialist hero is anathema to the needs of the black cause in the 1960 's and '70's. Even in his most assertive moments he appears curiously defensive. His triumphs are temporary. Although he is provided with the privilege of a usable racial past and a sense of community, the value of these resources is heavily restricted. The usable part of his past is limited to the black urban experience, the Southern folk culture being dismissed by Sonny as 'that old-time, down-home crap.' For all his discovery of a racial community, he remains the solitary individual going it alone. History are recognized as resources, but they can only be of help in enduring the paralyzing feeling of absurdity which is a symptom of white decadence in the first place. From the point of view of the engagt black literature of recent years, Baldwin's vision is too pessimistic, individualistic, and white-oriented to be acceptable.

Thus, ironically, the very qualities which were meant to prove Sonny's universal humanity and modernity, and hence his equality with the white man, were what made him most offensive in the eyes of the next generation of black writers. What Sonny proved to Greenlee and Kelley in the 1960's was not his equality with whites in a commonly shared humanity, but his author's submission to the allegedly decadent values of a decaying Western civilization. The ideological situation confronting the black community and the black 
writer in the post-civil-rights era was to require an esthetic and a conception of literary character very different from those that produced Baldwin's musician-hero.

\section{2.}

Constantly making their way into Kelley's fictional world are the echoes of the civil rights revolution, soul, and the black nationalism of the 1960's. Dancers on the Shore is a transitional collection, reflecting the tensions of the decade. The author's preface, referred to above, indicates the conventional moral and esthetic premise from which he started out, but it can hardly be said to apply to all the stories in the volume. In some of them, a note of growing militancy is clearly discernible. The specific targets of such stories as 'Connie' and 'A Visit to Grandmother' would seem to be the black bourgeoisie, and it is not difficult to recognize in 'The Servant Problem' an early version of the first pages of the 'Opal'-section of dem (1967), the novel which is Kelley's most explicit satire of white America to date.

The points of juncture between literature and ideology in 'Cry for $\mathrm{Me}^{\prime}$ are particularly clearly visible in the range of characters inhabiting the story. White people are an amorphous mass, either parading their opulance at Carnegie Hall concerts or producing their pathetic mass entertainment within the racist conventions of the antebellum Plantation Tradition. The lightskinned or 'yellow' black is discredited by association with sexual perversion and a phoney relationship to black folklore. The urban black - typified by the narrator - is also castigated for his willing adoption of the vices of the decadent city, alienated from race and folk, and immersed in the cheap popular mass culture of contemporary America. By contrast, the dark unadulterated soul Negro of Southern rural background and steeped in the folklore of his racial group is celebrated and mythologized to an extent which strongly suggests concerns on the author's part beyond strictly literary creation.

Kelley's presentation of Uncle Wallace makes him a figure of romantic romance. Such figures are, in the words of Marius Bewley discussing Jay Gatsby, 'mythic' characters '.. . whether of fact or fiction, insofar as they express destinies, aspirations, attitudes typical of mar, or particular groups. ...' They are 'impersonal' with no distinction between their public and private lives, existing 'for the inspection and instruction of the race. ${ }^{27}$

This description fits Kelley's musician-hero remarkably well. His private life story is as uninteresting as is Gatsby's. Wallace has, in 
fact, no private life, no meaning or destiny as an individual. A completely unself-conscious character, he makes sense only in relation to the racial group. His primary function is public and symbolic: that of embodying tensions and trends alive in the culture, and of symbolizing a new mythos.

Kelley goes even further than Baldwin in creating a mythic halo around the musician-hero. Unlike Sonny, Wallace is not individualized. Psychologically, he has neither depth nor complexity. Next to no information is given to provide him with a realistic past or social context. His life prior to his arrival in New York is shrouded in a misty history of heroic ancestors. The implication is that he belongs to a line of strong men, one of whom-his father-has got his almost supernatural feats of physical strength immortalized in one of Wallace's songs. He is believed by Carlyle to have been 'close to eight feet and made of some kind of fireproof metal.' Wallace himself cuts an impressive figure with his 'size of a black Grant's Tomb,' punching his brother 'square in the chops so he flew back about twenty feet.' The joint work performance of Wallace and his brother equals that of eight ordinary construction workers, and he claims to have sung 'from Friday until the next afternoon.'

As befits the mythic hero, Wallace transcends the laws governing the lives of ordinary mortals. His death remains a mystery defying classification in the categories of human knowledge. Standing around the dead body, the doctors can only shake their heads, unable to explain how he died: 'Their wasn't a mark on him, but he was dead all right.' Dismissing the case as inexplicable, one of them says: 'There is nothing wrong with him, except he's dead.'

The mythic dimension is further reinforced by analogy with heroes of myth and legend. Wallace is a 'big voice crying in the wilderness,' suggesting a white wasteland world awaiting the coming of the heraldic voice of soul. In the larger context of Kelley's fiction, there is considerable evidence in support of such an interpretation. With increasingly strong emphasis, the saving power of soul in a morally bankrupt white culture has been a major emphasis from as far back even as A Different Drummer. The only way for the white man's civilization to survive is, in Baldwin's French phrase, to 'se négrifier,' ${ }^{28}$ or, in the vocabulary of Ishmael Reed's Mumbo fumbo, to surrender to the dionysian virus of the 'jesgrew', now operating in Euro-American culture.

Although explicitly disclaiming any church affiliations, Wallace 
is equipped with semi-divine attributes setting him apart from his surroundings. Wherever he goes, he generates an atmosphere of religious solemnity. The cabaret in which he performs is appropriately called The Lantern, implying the idea of light in a dark world. Entering for the first time, he discovers a light-colored homosexual folk singer faking the emotion of one of Wallace's most highly treasured songs. Outraged at such a sacrilege, Wallace drives the faker off the stage in a way that suggests Christ chasing the money lenders out of the synagogue. His performances produce an awed silence in the audience as the message is communicated. This representation of the scenes of Uncle Wallace's presence as holy ground is further reinforced in the explicit description of his guitar chords as similar to the sound of 'an organ in church.'

In but not of this world, Wallace exhibits further characteristics normally associated with figures of myth and legend. Thus Carlyle comments that 'Uncle Wallace was innocent.' Untainted by the corruption of society, he can only stare blankly and with utter incomprehension at his relative when faced with its strange ways. His guided tour of New York's underworld of sexual perversion is surrounded by vaguely mythic overtones underscoring the heroic purity of his heart. His innocence of technology is no less 'mythic.' Unfamiliar with modern recording techniques, he allows a professional folklorist to record all his songs for 30 dollars. Finally, Wallace is totally ignorant of the existence and practices of the show business establishment. Approached by a concert producer who wants him to perform at Carnegie Hall, he is confused beyond words and turns to Carlyle for an explanation of Mr. Berger's commercial exploitation of art. In every instance, the laughter is directed, not at Wallace, but at the producer's pretentious speech and appearance or at the miserly treatment of the black singer by Francis Mazer, on whose name Kelley pulls a pun indicating the intended object of his ridicule.

Wallace's innocence is the radical innocence of the mythic hero. He cannot be contained within the human moral categories of sin, guilt, and forgiveness, or within the worlds of technology, economics, and politics. His innocence and virginity are primordial, raising him to the level of a demigod. In the final scene, he is established as an object of dionysian celebration and worship in his temple, possessing healing powers of which the audience vicariously partake by touching his body: 'The people was rushing toward him. They was all crying and smiling too like people busting into a 
trance in church and it seemed like everybody in the place was going on stage, trying to get near enough to touch him, grab his hand and shake it and hug him and kiss him even.'

An important point is Kelley's association of Wallace with the folk hero John Henry. Besides such externals as Wallace's bulky appearance and herculean strength, other more indirect analogies can be found. The legendary steel driver's racial purity is paralleled by Wallace's dark complexion and Negroid features. As John Henry was said to be capable of breaking the best worker in the country, so Wallace and his brother can outwork eight regular workers. Carlyle reveals that his uncle's white dinner jacket was won in 'some kin-a contest driving piles, or cutting wood.' In the film he plays in, Wallace sings 'John Henry,' and the narrator makes it clear that of all the songs his uncle sang, he prefers 'Cotton Field Blues' and 'John Henry.' He returns to the movie theatre over and over again to hear the two-minute song number which is the only thing in the film that is not 'cardboardy.' The suggested relationship between Wallace and the folk ballad hero is a major clue to the meaning of the story.

With the mythic mode thus established, the problem arises of how to interpret the intellectual and ideological sources of the story's musician-hero. As an artist thoroughly grounded in the tradition of modern American prose writing, Kelley's work frequently suggests the influence of the myth-making imaginations of Faulkner and Hemingway. From a structural and functional point of view, it is tempting to see Wallace as a character patterned on what Philip Young has called the 'code hero' in Hemingway's fiction. ${ }^{29}$ Like Pedro Romero, he serves to illustrate to Carlyle and the new generation of blacks 'wounded' by the decadence of modern urban America a 'code' which could restore to them a sense of identity and manhood. A Noble Savage to whom his urban nephew, for all his sympathy, can only have the distant, impersonal relationship one has to a symbol or an idol, Wallace bears perhaps a more than casual resemblance to Hemingway's bullfighter-priest with whom no mortal can be lastingly involved. At no point in the story does Carlyle see his uncle in personal terms as an individual. To him, Wallace is a 'voice' speaking with increasingly greater authority and revealing to him the mysteries of his kingdom of blackness.

Wallace is blackness distilled to its pure, primordial state, the incarnation of the unadulterated black identity that LeRoi Jones's Clay Williams feels stirring inside him but never dares to assume 
fully. To represent this black ur-soul Kelley uses a pre-Northern Negro in all his presumed cultural and psychic wholeness. In perfect accordance with the ethos and ideology on which he is predicated, he derives his strength not from intellect, but from instinct, passion, and intuition. Or better perhaps, he is uncontaminated by the white Western dualism which reductively imposes upon the dynamic wholeness of human existence such dichotomies as head versus heart, abstract versus concrete, reflection versus action, individual versus group, and art versus life. His behavior is peculiarly unpremeditated. Like Tucker Caliban in Kelley's first novel, Wallace fuses such dualities. Just as Tucker and the other 'new Negroes' in A Different Drummer, Wallace too acts spontaneously out of some deeply felt and thought inner urge reminiscent of Senghor's idea of the unfragmented African psyche. His coming North was an act of this kind: 'He sent us a telegram; there wasn't enough time for him to write a letter because, he told us later, he only decided to come two days before he showed up.' Similarly, his artistic performances are spontaneous, voluntary acts never undertaken for profit or fame, and never perceived as 'high art' involving categorization into creator, artistic object, performer, and audience. His concerts are communal moments of sharing in which such categories become meaningless. Wallace's view of art stands in demonstratively clear contrast ro the coolly calculating attitude of Mr. Berger, and even Carlyle, who treat Wallace's art as a field of investment, or the attitude of the Carnegie Hall audience who see the concert as social occasion and as detached enjoyment of an artistic object.

With perfect consistency, Kelley never has Wallace articulate and conceptualize his ontological assumptions, but live them. Applying the vocabulary of James Stewart prescribing a new 'cosmology' or 'reality-model' for the black artist, ${ }^{30}$ one might describe Uncle Wallace's vision of the world as implicitly nonscientific and non-mechanical. In terms antithetical to the white, Western conception of reality, the black man conceives of the world as endless becoming, a state of perpetual flux to be embraced and lived rather than divided, arrested, fixed, and preserved. Life is seen as an all-inclusive process of eternal creation through dialectic reconciliation of conflicting forces in which art cannot be singled out as a separate and specialized activity to be cultivated in isolation for its own sake or as exclusive self-expression. Wallace is conceived in the African image of the tribal artist whose art is perishable and recreated each time, integrated into the life of the com- 
munity to the point of becoming indistinguishable from it. Wallace does not so much produce art objects as he recreates with each musical act the aboriginal black self in communion with the life force itself. In his art, there is no distortion of reality to create illusions of truth. He just picks up his guitars and plays as the spirit moves him, artlessly and unself-consciously, affirming and celebrating la force vitale.

This interpretation receives support from Kelley's own claim elsewhere that 'African writers and most non-Western writers do not make a separation between art and life. Art and life and politics are all tied together ... Our literary tradition is essentially the African literary tradition ... I think that the mythic, the supernatural, tradition is much more the way we think.'31 Although this statement was made three years after the publication of Dancers on the Shore, there is little problem in applying it retroactively to 'Cry for Me.' In fact, placed as it is at the end of the volume, this story foreshadows Kelley's development toward a more explicitly separatist esthetic in $A$ Drop $₫$ Patience-also featuring a musicianhero- and dem.

Furthermore, Wallace's soul ethos implicitly repudiates the individualism so highly treasured in the white man's culture. Coming back to Bewley's description of the mythic hero, one might describe Kelley's black musician as a character who cannot be meaningfully defined in terms of a private destiny. In Wallace the public and the private merge. Emerging out of a family, racial, and regional past, he lives and plays 'for the inspection and instruction of his race,' returning to his ancestral origins in death. In Carnegie Hall, he instinctively responds to the presence of a group of fellow blacks in the audience, although they are almost unknown to him. Bringing them on stage, he integrates them into the performance as a matter of course and without any sense of distance between them. No mere trick of composition or sentimental indulgence, this incident would seem intended to symbolize the natural fusion of individual and group in an imagination untainted by compartmentalized thinking and reductivist formulas. Wallace's emotional instincts are communal rather than individual, and his fulfilment lies in group involvement rather than in personal achievement. No ethic of selfmade success, based on a Darwinist social philosophy of the struggle of the self-reliant individual against the restraints imposed by a hostile society, can adequately explain Wallace's achievement. Such 'white' concepts are alien to his black soul sensibility. 
Implicit in Wallace's 'code' and conveyed through analogy with John Henry is the rejectio of industrialism and the machine inherent in the soul ethos. Though a perennial theme in American intellectual history, Kelley's idea here, or at Least the impetus to use it, is more fruitfully related to African or Afro-American ideological currents in the 1960's. It should be noted, however, that his use of folklorc is too sophisticated to land him in a reactionary agrarianism simplistically and programmatically dismissing modern industrial civilization. All the time moving on the level of myth, he is able to score his points and avoid any criticism that might come from too literal readings of the story. The symbolic steam drill which forces the steel driver to perform almost supernatural feats of strength is as much Wallace's enemy as it was John Henry's. It suggests a monstrous force mercilessly subjecting men to inhuman ends in the interests of profit and productivity. An agent of chaos and disruption, it implies a denial of the harmonious unity of man and his natural environment. Its predatory nature thrusts upon men in society a competitiveness which separates them and drives them apart. The counterpart to the steam drill in Kelley's story is the New York City with which Wallace engages in a mythic struggle with his guitar and voice and which he ultimately conquers in spite of his physical death. The city's victory is a Pyrrhic one. After the destruction of the body, Wallace's black soul goes marching on, as reflected in the urban Carlyle's gradual awakening to the truths of his uncle's message.

Another implication of the soul ethos that $\mathrm{Kelley}$ is able to communicate through analogy with John Henry is the alleged sexual superiority of the Negro. Greatly helped by Norman Mailer's 'The White Negro,' recent black nationalism bas frequently tended to embrace the traditional white myth of the Negro's superior virility, turning it into a counter-mythology with connotations of black sexual superiority. A famous statement of this counter-mythology is Eldridge Cleaver's Soul on $I_{c e}$, which includes explicit laudatory references to Mailer's essay with accompanying diatribes against blacks who, like James Baldwin, refuse to accept Mailer's thesis and are therefore liable to charges of racial self-hatred. Similar overtones can be discerned in the other literary genres, and they have been noted by the anthropologist Roger D. Abraharns who writes that "Soul" has a sexual dimension to its meanings. ... Soul has ... become a euphemism for sexual drive. ${ }^{232}$

Kelley first alerts us to this aspect of his hero through Carlyle's 
words that 'the most important thing about him was that he wasn't some guy singing about love who never loved, or hard work who never worked hard, because he done all that, loved women and picked cotton and plowed and chopped trees.' The analogy with the ballad hero reinforces this impression through the obvious Freudian implications of John Henry's story. In the words of Richard M. Dorson: 'The steel-driver shaking the mountains is a phallic image; singers know that John Henry died from lovemaking, not over-work:

\section{This old hammer - WHAM! \\ Killed John Henry - WHAM! \\ Can't kill me-WHAM! \\ Can't kill me-WHAM!}

Thus the hammer song vaunted the sexual virility of the pounder.'33

Wallace is a far cry from the Mailerian idea of the Negro as a healthy psychopath, the counterpart to Colin Wilson's charismatic outsider: the natural existentialist and forerunner of the hipster type, denied 'the sophisticated inhibitions of society' and forced to develop a counter-cultural life style in which sexual performance became the primary value and the highest art. For all the intensity of his rhetoric, Mailer's black hipster remains a rather helpless abstraction more effective for what it betrays about the author's despair in a bourgeois intellectual-puritanical culture than for anything it expresses about the black condition. Kelley's Wallace has no need to flaunt his sexual prowess. The point about his superior virility is made through allusion to and analogy with the celebrated sexual powers of one of his racial ancestors. Unobtrusively, the author suggests a continuity between John Henry and Wallace while simultaneously intimating that this is a black asset.

Finally, soul harks back to the Southern experience. This embracing on Kelley's part of the Negro's folk roots runs counter to the rejection or, at best, ambivalence, that has traditionally characterized the black bourgeoisie. This middle-class hostility to Southern folk culture has been analyzed by such scholars as Harold Cruse and E. Franklin Frazier, ${ }^{34}$ and has received fictional treatment in the works of Charles W. Chesnutt, Jean Toomer, and later writers. A more oblique, but no less revealing statement of the same ambivalent feelings is the exchange between the white critic Stanley Edgar Hyman and Ralph Ellison in 1958. ${ }^{35}$ Ellison, following Hyman's attempt to locate the sources of the role playing trickster 
archetype in the tradition of blackface minstrelsy, makes a heroic effort to disclaim the trickster's black origin by establishing him as a white American archetype originating with the Revolutionary Wars and the birth of the Republic, which created the need for role playing and masks as a substitute for an as yet non-existent national identity. Ellison's eagerness to avoid association of the negative connotations of the trickster with the Negro can be seen as an indication of the frustrated attitude of the black middle-class intellectual toward his folk past, even as he professes to embrace it and use it in his own work.

Kelley's story lends itself readily to interpretation in terms of the growing pride in the Negro's Southern folk roots in the 1960's. In A Different Drummer and Dancers on the Shore the author-himself a Northern, urban black - returns to the Southern heritage both for materials and for soul with which to infuse them. Uncle Wallace is no primitive Southern black duped by the wicked ways of the big city. His career in New York is cast in the form of a crusade with unadulterated moral and spiritual strength triumphing over decadent sophistication. Described with deliberate absence of realistic detail, the Southern background acquires mythic overtones of heroic loving, singing and working against a suggestively vague tableau of floods and natural disasters inspiring men to herculean feats of strength. It is out of this mythic mist that Wallace emerges to conquer the city with which he engages in battle. In the present age, the challenges to black soul strength are not the natural forces his father fought, but the more insidious forces of New York's phoney 'yellow' blacks, the 'high' culture of Mr. Berger and the Carnegie Hall crowd, and the commercial movie industry with its 'cardboardy' ante-bellum notions of the Southern planter aristocracy. Fortunately, the symbolic confrontation of the city and the rural past does not degenerate into a simplistic agrarian fantasy. Carlyle survives, and there is every indication that the young black narrator will remain in the city, applying his uncle's message in a modern urban setting. Nor is his 'conversion' a naive, adolescent hero admiration, but a reluctant and gradual insight, remaining somewhat inconclusive as the story ends. At the same time, it is clear that through his Southern relative, Kelley's contemporary urban Negro has found a viable myth by which to live in a world of urban complexity.

The above should indicate the debt owed by Kelley to some of the central assumptions and ramifications of the Afro-American soul 
ethos in his use of the black musician as literary hero. Wallace is soul made visible and elevated to the level of a mythic construct for the use of the race. The further implication is that the new black ethos possesses revitalizing virtues of which contemporary America stands in great need. In several scenes, Uncle Wallace may come close to the brink of notions of the black man's innate superiority, but Kelley manages through an ultimately interracial perspective and Carlyle's realism to stop short of active advocacy of narrowly racialist implications. However strenuously the story exerts itself to assert the unquenchable spirit of blackness, the author avoids indulgence in a sentimental mystique. Wallace is firmly anchored in American culture. He is no exiled African entertaining romantic notions of returning to the Mother continent. Wallace's roots are in the South, just as Carlyle's are in the modern American city. Nor is there an exclusive insistence on narrowly separatist notions of racial self-sufficiency. Wallace will play for any audience, black white, or interracial, and the ultimate goal of his black folk art is to humanize his fellow men irrespective of race, creed, or color: '. . . he'd taken all them people, and sung to them, and made them forget who they was, and what they come from, and remember only that they was people.' The impact of the music is the same on everybody in the audience. Attempting to articulate the gut cffect of Wallace's voice through metaphorical equation with violent stomach pains or sexual orgasm, Carlyle speaks for the whole interracial audience without making any special claims for an exclusive black sensitivity to the truths of soul, inaccessible to others. In the 'church' of his performances, the musician-priest is black, but he ministers equally to the needs of everybody. The same impression is conveyed in his first novel where Kelley buttresses his case for the black Tucker Caliban's moral and spiritual independence by supportive allusions to Thoreau's Walden and Shakespeare's The Tempest. Through such allusions, the author links the virtues of his hero's black ethos to valuable elements in the Euro-American heritage in much the same way that Ishmael Reed's Mumbo Jumbo integrates the black 'jesgrew' life style into an all-inclusive philosophy of history in terms of the Dionysian principle in Western culture. The vision emerging from such a broad awareness is impressive indeed, and one can only regret that in dem Kelley shows symptoms of backsliding into a more narrowly based racial mystique.

Another measure of Kelley's artistic control is the realism built 
into the use of point of view. Counterbalancing the story's straining toward myth and symbol is the narrator's urban, pragmatic imagination through which everything is filtered. The point of view restricts the reader to $\mathrm{Ca}$ lyle's perception of his uncle. Ultimately then, what we observe is the process of mythmaking in the narrator's skeptical mind as he grows from seeing his uncle as a relative to an awareness of him as a force, a symbol and, eventually, a fullfledged myth. This process is gradual and reluctant, and not entirely completed. Immersed in the white-dominated secular mass culture of the big city, he has dissociated himself from fertile contact with the cultural roots of his race to the point of all but losing his ability for spiritual perception. He feels as amed of Southern blacks whom he sees as 'all bulgy-eyed and confused,' and of Uncle Wallace on Times Square or at his first performance at The Lantern. His descriptions of his uncle frequently carry a note of impatience and condescension. He does not 'dig' the folk music or the blues, and 'John Henry' in particular is incomprehensible: '. . . what an idiot this John Henry must-a been, killing his-self to beat a machine when he could-a joined a union, like my old man's, and made twice the money and kept the machine out.' It is clear that at first he cannot grasp Wallace as a symbol. When a newspaper story establishes Wallace as a 'voice speaking for all the colored folks' and communicating 'the pain of discrimination and segregation,' this seems to Carlyle 'like a lot of B-S . . because I didn't understand Uncle Wallace hardly myself; I didn't understand why he sang folk songs when he could sing rock-and-roll or jazz.'

By the end of the story, however, Carlyle has come a long way toward seeing the significance of Uncle Wallace and accepting him as a viable myth by which to live and restore true spiritual vision in a secular, materialistic culture. However, employing the device of dramatic irony, the author does not permit his narrator to grasp the full meaning of the musician-hero. Carlyle's initiation, however genuine, stops short of full adult, conscious understanding, which can be explained both on grounds of psychological credibility and esthetic logic. By withholding full awareness from his narrator, Kelley escapes the mistakes of Sherwood Anderson and Salinger in failing to provide their adolescent narrators with adequate moral and intellectual capacity by making them too young to carry the burden of their stories. In 'Cry for Me,' the full import of the story is ultimately contained in the ironic discrepancy between the story teller's partial vision and the larger vision of the reader. Rather 
than having Carlyle see, understand, and spell it all out, the author has chosen to leave a richly suggestive slice of reality to be acted upon directly by the reader's imagination.

3.

Pursuing O. Mannoni's and George Lamming's intriguing suggestion that the relationship between Prospero and Caliban in The Tempest can be read as a paradigm of the relationship between ruler and subject in a colonialist society, Janheinz Jahn has explored the possibility that Caliban might refuse to remain imprisoned within his master's prescriptive definition of the language he has been taught. ${ }^{36}$ To be sure, he will always remain dependent on Prospero's language, and he will always understand his master's use of it. But Caliban might discover that his culture is not confined to the colonist's books, and that the magic powers and the magic knowledge possessed by his native tribe constitute a valid and legitimate culture even though Caliban can only invoke it in images. Once he has discovered and self-consciously claimed this heritage, he may start minting a new language out of Prospero's imported words and concepts. For all its superficial resemblance with the original, Caliban's derivation will be a new and unique creation which can only be partially grasped by the master and of which he is constantly in danger of missing essential meanings. The slave will have created a new medium of his own, no longer identical with the one he was once taught. Caliban will have broken Prospero's hold on him while continuing to understand Prospero's language.

As they reveal themselves in their respective stories, Baldwin and Kelley provide illustrative examples of the black American Caliban in various stages of his development toward a new racial and cultural self-consciousness and consequent adoption of the white Prospero's language for his own uses. In 'Sonny's Blues,' the author is Caliban expanding Prospero's framework by infusing it with the magic of his particular island. And yet, for all his familiarity with the blues, Sonny's ultimate source is to be found in Prospero's culture. Baldwin's hero is a Euro-American existentialist dressed up as a black blues musician. Denouncing Louis Armstrong's art as 'that old-time, down-home crap,', he reveals that he has no use for his folk roots in the South. His relationship with the black community in the North is also somewhat ambivalent. While seeking to identify with it through the music, he is nevertheless trying to escape it. Baldwin leaves Sonny playing not in Harlem among his own 
people, but in Greenwich village to an interracial audience. This is not denying either the authenticity or the validity of Baldwin's portrait of the black musician as existentialist, but the point should be reiterated that in the final analysis the emphasis is on Sonny's existentialism rather than on his blackness. On the background of the urgently felt need to secure acceptance and integration of the race in the first post-war decade, Baldwin's story dramatizesbeyond its autobiographical elements and purely narrative logicthe strategy of the black intelligentia of seizing upon a white concept in order to 'negrify' it and pass the hybrid off as a symbol of a commonly shared humanity.

Kelley's strategy in the following decade was to reverse this process, as should be expected from a Caliban in a more advanced stage of racial self-consciousness. Starting with an image of the aboriginal black self still extant on the Afro-American island, this author exploits the resources of Prospero's Christian symbolism, Freudian psychology, and ideas of literary art to project a hero who, for all his analogy with a Hemingway 'code hero' or a Faulknerian myth, remains a black magician. Essentially, Wallace is soul energy, claimed and appropriated through the language and concepts he was once taught and which he has now refashioned. He is Caliban after he has broken out of his master's prison.

Kelley, however, has cot succumbed to the temptation of making Caliban's experience inaccessible to the white American Prospero. The goal of Wallace's art is to humanize everybody in the audience and to make them conscious of their common humanity. This is not to be confused, however, with the traditional pleading for equality. Equality is automatically assumed with Wallace being offered as a symbol of a revitalizing ethos which could lift the curse on the modern American wasteland. The responsibility of answering this challenge is placed squarely on the shoulders of the oppressor. But at least the oppressor is deemed worthy of attention.

\section{NOTES}

1 Edmund Fuller, Man in Modern Fiction, New York: Random House, 1958, p. 7.

2 Hugh M. Gloster, 'Race and the Negro Writer,' Black Expression, ed. Addison Gayle, Jr., New York: Weybright and Talley, 1969, p. 257. Originally published in 1950.

3 Collected in Going to Meet the Man, New York: Dell, 1965. 
4 'Autobiographical Notes,' Notes of a Native Son, New York: Bantam, 1959, p. 6.

5 Significant essays by Césaire, Diop, and Senghor have been collected in Anthologie Négro-Africaine, ed. Lilyan Kesteloot, Verviers, Belgium: Gérard \& Company, 1967. The concept of Négritude has received extensive treatment by Janheinz Jahn in Neo-African Literature, New York: Grove Press, 1969. Other critical essays are 'Negritude: Literature and Ideology' by Abiola Irele, Modern Black Novelists, ed. M. G. Cooke, Englewood Cliffs, New Jersey: Prentice-Hall, 1971, pp. 13-23, and The Black Militant Writer in Africa and the United States by Mercer Cook and Stephen E. Henderson, Madison: The University of Wisconsin Press, 1969.

6 Cook and Henderson, op. cit., p. 127.

7 Preface to Dancers on the Shore, Chatham, New Jersey: The Chatham Booksellers, 1964.

8 Collected in Dancers on the Shore.

9 Marcus Klein, After Alienation, New York: Meridian Books, 1972, pp. 172173.

10 Shirley Anne Williams, Give Birth to Brightness, New York: Dial Press, 1972, vV. 145-146.

11 Edward Margolies, Native Sons, Philadelphia and New York: Lippincott, 1968. p. 107.

12 Collected in Notes of a Native Son.

13 Phylon, Voi. 23 (1962), pp. 359-371.

14 Nathan A. Scott, 'Search for Beliefs: Fiction of Richard Wright,' University of Kansas City Review, Vol. 23 (1966), p. 19.

15 'How Bigger Was Born,' Twentieth-Century Interpretations of Native Son, ed. Houston A. Baker, Jr., Englewood Cliffs, New Jersey: Prentice Hall, 1972, pp. 2147 . Parts of the article originally appeared in the Saturday Review of Literature, Vol. 22 (June 1, 1940).

16 White Man, Listen!, New York: Doubleday, 1964, pp. 71-72.

17 Notes of a Native Son, p. 104.

18 The Peculiar Institution, New York: Random House, 1956, p. VPI.

19 The termis used by George Lukacs in his essay'The Intellectual Physiognomy of Literary Characters,' Radical Perspectives in Art, ed. Lee Baxandall, Harmondsworth: Pelican, 1972, pp. 89-141. Originally published in 1936.

20 Quoted from Sartre's Existentialism and Humanism (1946) in The Modern Tradition, eds. Richard Ellman and Charles Feidelson, Jr., New York: Oxford University Press, 1965, pp. 842-843.

21 Søren Kierkegaard, The Sickness unto Death, translated by Walter Lowrie, Princeton, New Jersey: Princeton University Press, 1941; Jean Paul Sartre, La Nausée, Paris: Gailimard, 1961 ; Albert Camus, L'Etranger, Paris: Gallimard, 1970.

22 Camus, The Rebel, Harmondsworth: Penguin, 1962.

23 Quoted from Camus's The Myth of Sisyphus (1942) in The Modern Tradition, p. 845 .

24 Ralph Ellison, Shadow and Act, New York: The New American Library, 1964, pp. 90, 104.

'25 Ellison, Invisible Man, Harmondsworth: Penguin, p. 469.

'26 'Sonny's Not Blue,' collected in Black Short Story Anthology, ed. Woodie King, New York: Columbia University Press, 1972.

27 Marius Bewley, 'Scott Fitzgerald's Criticism of America,' Twentieth-Century Interpretations of The Great Gatsby, ed. Ernest Lockridge, Englewood Cliffs, New Jersey: Prentice-Hall, 1968, pp. 40, 44. Originally published in 1954.

28 Interview with L'Express, August 21-27, 1972, p. 69.

29 Philip Young, Ernest Hemingway, New York: Rinehart, 1952. 
30 James Stewart, 'The Development of the Black Revolutionary Artist,' Black Fire, eds. LeRoi Jones and Larry Neal, New York, William Morrow \& Company, 1968, pp. 3-10.

31 Jervis Anderson, 'Black Writing: The Other Side,' Dissent, Vol. 15 (1968), pp. 236-237.

32 Roger D. Abrahams, Positively Black, Englewood Cliffs, New Jersey: PrenticeHall, 1970, p. 144.

33 Richard Dorson, 'The Ballad of John Henry,' An American Primer, ed. Daniel J. Boorstin, New York: The New American Library, 1968, p. 463.

34 Harold Cruse, The Crisis of the Negro Intellectual, New York: William Morrow \& Company, 1967; E. Franklin Frazier, Black Bourgeoisie, London: Collier Books, 1969.

35 'The Negro Writer in America: An Exchange,' Partisan Review, Vol. 25 (1958), pp. 197-222.

36 Jahn, op. cit., pp. 239-242, 269. 